\title{
Temporal evolution of fault systems in the Upper Jurassic of the Central German Molasse Basin: case study Unterhaching
}

\author{
Ingmar Budach $^{1} \cdot$ Inga Moeck $^{2} \cdot$ Ewald Lüschen $^{2} \cdot$ Markus Wolfgramm $^{3}$
}

Received: 24 August 2016 / Accepted: 20 July 2017 / Published online: 23 August 2017

(C) The Author(s) 2017. This article is an open access publication

\begin{abstract}
The structural evolution of faults in foreland basins is linked to a complex basin history ranging from extension to contraction and inversion tectonics. Faults in the Upper Jurassic of the German Molasse Basin, a Cenozoic Alpine foreland basin, play a significant role for geothermal exploration and are therefore imaged, interpreted and studied by 3D seismic reflection data. Beyond this applied aspect, the analysis of these seismic data help to better understand the temporal evolution of faults and respective stress fields. In 2009, a $27 \mathrm{~km}^{2} 3 \mathrm{D}$ seismic reflection survey was conducted around the Unterhaching Gt 2 well, south of Munich. The main focus of this study is an in-depth analysis of a prominent $\mathrm{v}$-shaped fault block structure located at the center of the 3D seismic survey. Two methods were used to study the periodic fault activity and its relative age of the detected faults: (1) horizon flattening and (2) analysis of incremental fault throws. Slip and dilation tendency analyses were conducted afterwards to determine the stresses resolved on the faults in the current stress field. Two possible kinematic models explain the structural evolution: One model assumes a left-lateral strike slip fault in a transpressional regime resulting in a positive flower structure. The other model incorporates crossing conjugate normal faults within a transtensional regime. The interpreted successive fault formation prefers the latter model. The episodic fault
\end{abstract}

Ingmar Budach

Ingmar.Budach@gtn-online.de

1 Geothermie Neubrandenburg GmbH, Straße der Pariser Kommune 38, 10243 Berlin, Germany

2 Leibniz-Institut für Angewandte Geophysik (LIAG), Stilleweg 2, 30655 Hannover, Germany

3 Geothermie Neubrandenburg GmbH, Seestraße 7A, 17033 Neubrandenburg, Germany activity may enhance fault zone permeability hence reservoir productivity implying that the analysis of periodically active faults represents an important part in successfully targeting geothermal wells.

Keywords Geothermal exploration · Seismic interpretation · Tectonic evolution · Episodic faults · Slip and dilation tendency analysis $\cdot$ Foreland basins

\section{Introduction}

3D seismic measurements at Unterhaching were conducted in 2009 as part of the joint research project "Geothermal Characterization of karstic-fractured aquifers in Greater Munich" by LIAG and the LfU (Bavarian Environment Agency, Augsburg) (Lüschen et al. 2011, 2014). The aim of this study was to achieve an enhanced structural resolution of the Jurassic Malm aquifer, to characterize the aquifer for geothermal utilization and to incorporate the 3D data, together with available 2D seismic data, into a regional structural model of the Greater Munich area. The regional model was the basis for numerical simulations of the mutual thermo-hydraulic influence of geothermal production and reinjection wells in the model area (Schulz and Thomas 2012; Dussel et al. 2016).

The Unterhaching area (Fig. 1) was surveyed with a fixedspread layout of the receivers and a 300-fold common-midpoint coverage in the centre for $15-\mathrm{m}$ bin sizes.

The field configuration enabled processing for $7.5-\mathrm{m}$ bin sizes also and was characterized by a complete azimuth source-receiver range. For processing a dip-moveout (DMO) stacking scheme was used, followed by post-stack time and depth migration. The velocity model used for depth migration was better than to $1 \%$ precise when 


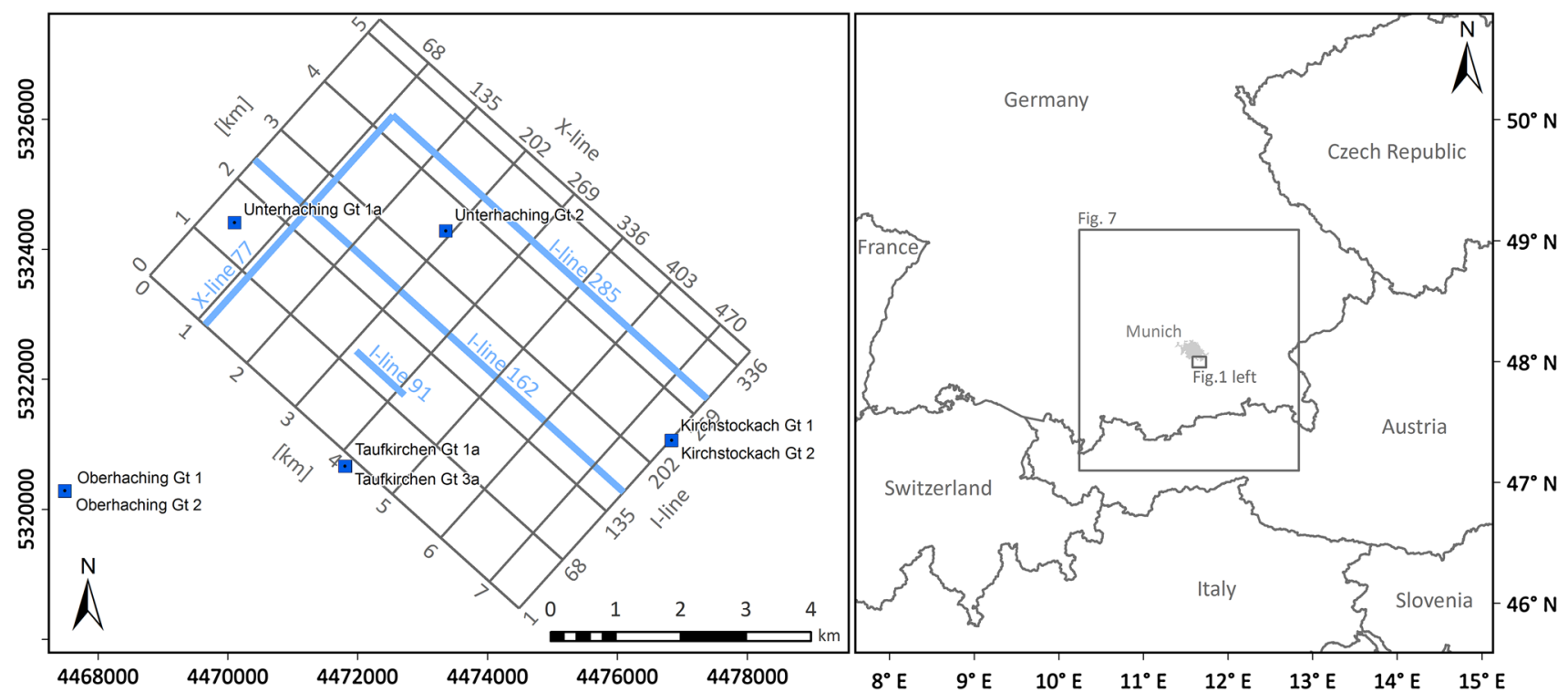

Fig. 1 Left location of the study area south of Munich (Germany) showing the area covered by 3D seismic survey and adjacent geothermal wells. Locations of the I-line and X-lines shown in Figs. 2, 3 and
5 are indicated by blue lines. Right locations of the survey area shown in left and of the map shown in Fig. 7

The most prominent reflection patterns of the Unterhaching survey are associated with Tertiary Molasse sediments, Lithothamnium limestone (Upper Eocene), Purbeck/Upper Malm and Base Malm (on top of Dogger and crystalline basement). Generally, the Malm aquifer is internally characterized by regions of chaotic and cloud-shaped reflection signals. These regions are partly intersected by planar reflection patterns, which can be interpreted as basin/lagoon facies. Regions with chaotic reflection patterns are characterized by relative seismic transparency, high seismic frequencies on their top (as evidenced by spectral decomposition), downlap structures at their edges and updoming hanging strata at their center. They can be interpreted as reef facies carbonates (Lüschen et al. 2014). Regions with reef facies have been a preferred target for geothermal drilling activities in the past since they are associated with enhanced karst dissolution and permeability enhancement due to dolomitization.

Several targets for geothermal exploration have been found by Lüschen et al. (2014): relay ramps in an en-echelon $70^{\circ}$ striking system of normal faults, the $45^{\circ}$ striking normal fault (penetrated by the Unterhaching Gt 2 well), a $25^{\circ}$ striking fault pattern, circular collapse structures (sinkholes) and zones of reduced seismic $\mathrm{P}$-wave velocities which correlate well with the location of fault zones.

These features are indicators of increased brittle disaggregation and enhanced fracture porosity. By means of azimuth-selective processing preferred orientations of these fractures could be imaged on a "sub seismic" scale (Lüschen et al. 2014). A thorough kinematic interpretation has not been performed yet, given the comparably small size of the 
study area (appr. $27 \mathrm{~km}^{2}$ ) and is subject of the paper presented here.

\section{Regional geology}

The study area is situated south of Munich (Germany) within the Bavarian Molasse Basin of the Alpine Foreland (Fig. 1). Its structural evolution and most important lithological units will be presented briefly.

\section{Structural evolution of the South German Molasse Basin}

The basement of the Molasse basin consists of Variscan granites and gneisses partly overlain by Permian-Carboniferous sediments (Bachmann et al. 1987). These sediments were deposited in NE-SW and NW-SE trending troughs and intramountain basins as result of post-orogenic late Hercynian wrench faulting subsequent to uplift and erosion of the Variscan orogeny (Vasela et al. 2008). Although the number, extent and depth of these post-Variscan troughs is still unclear due to sparse seismic and well data, this late Paleozoic structural grain may have governed the formation of the major zones of tectonic activity within the Bavarian Molasse Basin (Freudenberger and Schwerd 1996).

Probably during the Triassic, the Variscan relief was levelled and marine transgression started in the Jurassic. Between the Upper Triassic and Lower Cretaceous the Penninic Ocean opened along a NE trending rift zone and progressively flooded the southern European shelf, the so-called Vindelician land (Vasela et al. 2008). Upper Jurassic carbonates experienced complete submergence until probably early Upper Cretaceous when the collision of the African and European Plates at the end of the Mesozoic caused closure of the Penninic Ocean accompanied by regression and erosion (Bachmann et al. 1987).

Mesozoic strata thin from the western part in France/ Switzerland towards the eastern part of the Alpine Molasse Basin in Austria (Kuhlemann and Kempf 2002). In some areas, Jurassic carbonates rest directly on crystalline basement (Kuhlemann and Kempf 2002) indicating renewed tectonic stretching probably along pre-existing post-Variscan trough and graben faults. An indicator for reactivation of $\mathrm{NE}$ and NW oriented post-Variscan faults might be the NW to WNW and NE to ENE striking Mesozoic normal faults in Jurassic and Cretaceous successions evidenced by seismic investigation (e.g., Bachmann and Müller 1992). Normal faulting was active until the Early Tertiary, evidenced by the today's exposed horst block of the so-called LandshutNeuoetting High, bounded by NW striking normal faults (Bachmann et al. 1987). Synsedimentary normal faulting during the Cretaceous is documented from the growth of faults in the frontal part of the French Alps at the western part of the Alpine Molasse Basin (e.g., Welbon 1988), however little is known about synsedimentary normal faulting in the central or eastern basin part. Multiphase normal faulting and synsedimentary faulting during Tertiary is indicated from fault throw analysis in 2D seismic data in the central Alpine Molasse Basin (Moeck et al. 2015a). In the study area, located in the eastern central basin part, the major movements incorporating the highest throws took place during the Upper Cretaceous, e.g., after the deposition of Malm and Purbeck sediments (cf. Table 1).

The Coniacian/Santonian (Upper Cretaceous) marked the onset of tectonic upheaval in response to initiation of the Alpine orogeny, followed by synsedimentary subsidence, overall increase of faulting and the development of north dipping, antithetic secondary faults (Freudenberger and Schwerd 1996). Various seismic data from the German Molasse Basin covering the central and part of the eastern part of the Alpine Molasse Basin reveal normal faulting until at least the Lower Miocene (Moeck et al. 2015a). Mechanisms for normal faulting in foreland basins contemporary to thrusting in the adjacent orogenic belt is described, e.g., by Blisnuik et al. (1998) from the Himalayan thrust front development. Normal faulting in the uppermost crust is subject to crustal failure during flexure of the Indian plate in response to topographic loads by the growing orogenic belt. Normal faulting in foreland basins along strike and contemporary to thrust faulting may be supported by the increasing sedimentary load of Molasse deposits as erosional derivate from the adjacent mountain belt. Ultimately, these mechanisms may have led to the development of antithetic and synthetic normal faults parallel to the fold-and-thrust belt in the hinterland of the Molasse Basin (Bachmann et al. 1987).

Tectonic upheaval continued during the Tertiary until the Egerian (Upper Oligocene/Lower Miocene), which resulted in a further increase of fault throws at primary and secondary faults and lineaments. The existing tectonic setting was overprinted due to the $\mathrm{W}$ to $\mathrm{SW}$ oriented movement of the Bohemian Massif and the pre-existing lineaments (e.g., the Landshut-Neuoetting High) were distorted by lateral pressure (Freudenberger and Schwerd 1996).

Tectonic upheaval ended during the Upper Oligocene and a phase of relative quietness followed, which lasted until the end of the Middle Miocene.

A last episode of tectonic activity followed in the Middle till Upper Miocene with a further increase of throws along the main faults and lineaments (Freudenberger and Schwerd 1996).

\section{Relevant lithological units}

The 3D seismic measurements at Unterhaching were centered on the geothermal Unterhaching Gt 2 well. This 
Table 1 Stratigraphy, lithology and mechanical stratigraphy of Unterhaching Gt 2 well at the centre of the 3D seismic survey

\begin{tabular}{|c|c|c|c|c|c|c|}
\hline \multicolumn{4}{|l|}{ Stratigraphy } & \multirow[t]{2}{*}{ Depth TVD [m bgl] } & \multirow[t]{2}{*}{ Lithology } & \multirow{2}{*}{$\begin{array}{l}\text { Mechanical } \\
\text { stratigraphy }\end{array}$} \\
\hline & & Stage & Formation & & & \\
\hline \multicolumn{4}{|c|}{ Quaternary/Pleistocene } & 20.0 & Gravel, sand & Soft \\
\hline \multirow[t]{17}{*}{ Tertiary } & Middle Miocene & Badenian & $\begin{array}{l}\text { Southern full gravel } \\
\text { sequence }\end{array}$ & 110.5 & Gravel, sand & Soft \\
\hline & \multirow[t]{6}{*}{ Lower Miocene } & Karpartian & Sweet water beds & 560.5 & Sand, marl & Soft \\
\hline & & Upper Ottnangian & Kirchberg beds & 615.0 & Marl & Medium \\
\hline & & Middle Ottnangian & Glaukonitic sands & 686.5 & Sand & Medium \\
\hline & & & $\begin{array}{l}\text { Laminated marl } \\
\text { (Blättermergel) }\end{array}$ & 730.0 & Marl & Soft \\
\hline & & Lower Ottnangian & Neuhofen beds & 939.0 & Sand, silt & Medium \\
\hline & & Aquitanian & $\begin{array}{l}\text { Aquitanian beds } \\
\text { including Nantes- } \\
\text { buch sandstone }\end{array}$ & 1685.0 & $\begin{array}{l}\text { Sandstone, clay } \\
\text { marl, coal }\end{array}$ & Hard \\
\hline & \multirow[t]{3}{*}{ Upper Oligocene } & \multirow[t]{3}{*}{ Chattian } & Hanging claymarl & 1730.0 & Clay marl & Soft \\
\hline & & & $\begin{array}{l}\text { Sandy sequence } \\
\text { including Baustein } \\
\text { beds }\end{array}$ & 2385.6 & Sandstone & Medium \\
\hline & & & Lying claymarl & 2503.5 & Clay marl & Soft \\
\hline & \multirow[t]{4}{*}{ Lower Oligocene } & \multirow[t]{3}{*}{ Rupelian } & Claymarl & 2737.8 & Clay marl & Medium \\
\hline & & & $\begin{array}{l}\text { Ribbon marl (Bän- } \\
\text { dermergel) }\end{array}$ & 2777.2 & Lime marl & Soft \\
\hline & & & Light-colored marl & 2780.4 & Lime marl & Medium \\
\hline & & Latdorfian & Fish schist & 2783.6 & Claystone & Hard \\
\hline & \multirow[t]{3}{*}{ Upper Eocene } & \multirow[t]{3}{*}{ Priabonian } & $\begin{array}{l}\text { Lithothamnium } \\
\text { limestone }\end{array}$ & 2839.4 & Limestone & Hard \\
\hline & & & $\begin{array}{l}\text { Priabonian marl- } \\
\text { stone }\end{array}$ & 2861.8 & Lime marl & Medium \\
\hline & & & Base sandstone & 2874.4 & Sandstone & Medium \\
\hline \multirow[t]{5}{*}{ Cretaceous } & Upper Cretaceous & Turonian & Claymarl & 2906.5 & Clay marl & Medium \\
\hline & \multirow[t]{4}{*}{ Lower Cretaceous } & Barremian-Albian & Gaultian sandstone & 2934.9 & Sandstone & Very hard \\
\hline & & $\begin{array}{l}\text { Valanginian- } \\
\text { Hauterivian }\end{array}$ & Claymarl & 2939.4 & $\begin{array}{l}\text { Lime marl, clay } \\
\text { marl }\end{array}$ & Soft \\
\hline & & Berriasian & $\begin{array}{l}\text { Brecciated lime- } \\
\text { stone }\end{array}$ & 2945.0 & Limestone, breccia & Hard \\
\hline & & Purbeckian & $\begin{array}{l}\text { Calcareous greenish } \\
\text { fine sandstone, } \\
\text { Purbeckian lime- } \\
\text { stone }\end{array}$ & $\begin{array}{l}2956.5 \\
2967.1 \\
2977.6\end{array}$ & $\begin{array}{l}\text { Calcareous sand- } \\
\text { stone } \\
\text { Limestone, dolomite }\end{array}$ & Hard \\
\hline Jurassic & Upper Jurassic & $\begin{array}{l}\text { Thitonian Kim- } \\
\text { meridgian }\end{array}$ & $\begin{array}{l}\text { Franconian lime- } \\
\text { stone and dolomite }\end{array}$ & 3590.0 (final depth) & $\begin{array}{l}\text { Limestone } \\
\text { Dolomite }\end{array}$ & Hard \\
\hline
\end{tabular}

The soft Oligocene strata caused a decoupling of tectonic activity between the Mesozoic and the Tertiary (Fig. 2)

reached the Malm aquifer at a final depth of $3590 \mathrm{~m}$ TVD (total vertical depth). A lithological log is given in Table 1.

\section{Interpreted horizons}

Interpretation of the eight horizons shown in Fig. 2 was based on experience from other studies within the
Bavarian molasses basin (e.g., Schulz and Thomas 2012) as well as by using lithological markers from Unterhaching Gt 2 well (Table 1). The six lowermost horizons (Base Malm-Baustein beds) were used in this study. The Lithothamnium limestone is characterized by a distinct reflection below the Oligocene sediments and is often used as a reference horizon for interpretation of seismic data 
Fig. 2 Interpreted horizons at Unterhaching. Note the decoupling of tectonic activity between the Lithothamnium limestone and Molasse beds (Nantesbuch sandstone, Chattian, Baustein beds) due to soft Oligocene strata (Table 1). After semi-automatic horizons picking of the main horizons of interest. No vertical exaggeration. Location of I-line 162 shown in overview map in Fig. 1 left
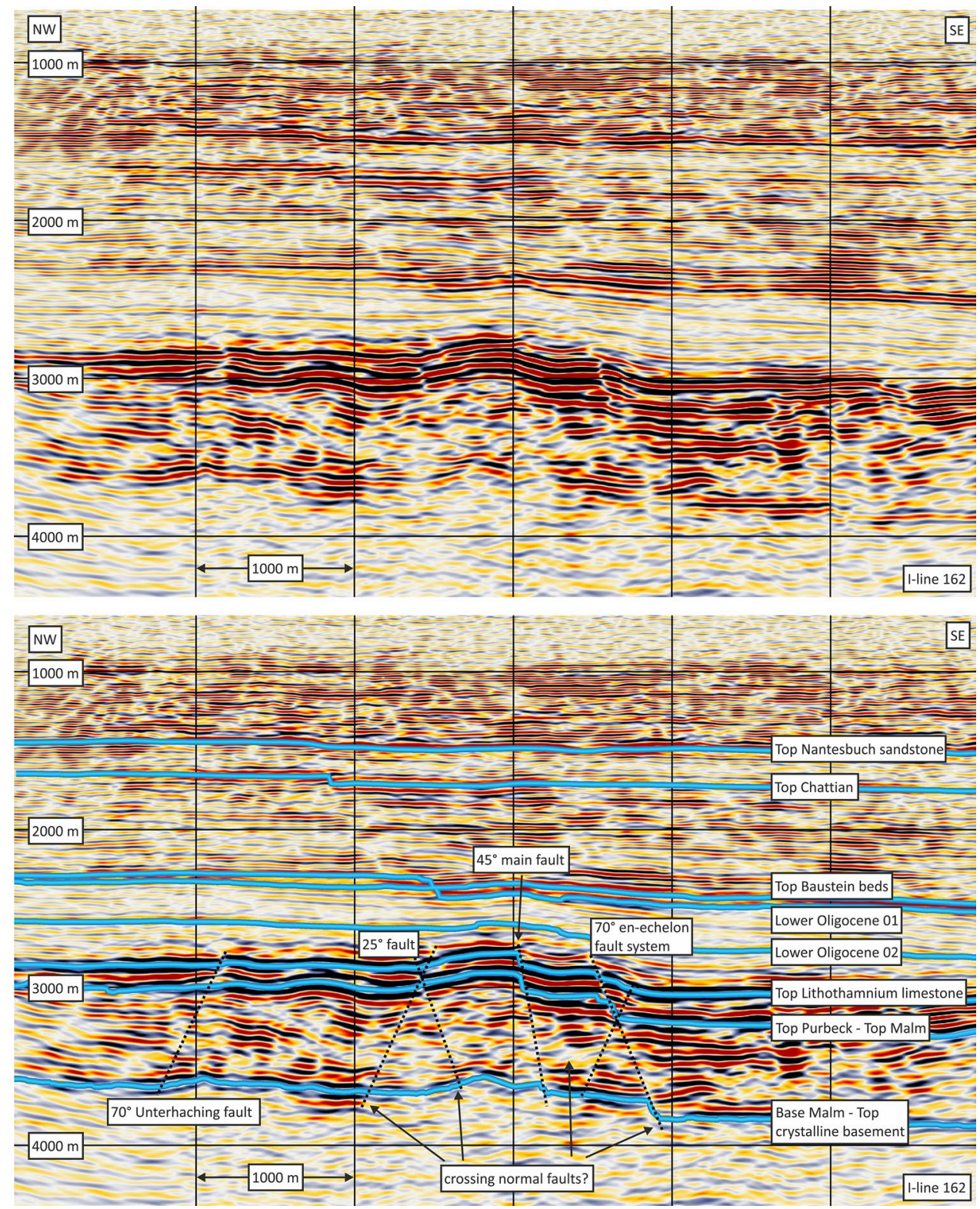

in the Molasse Basin (e.g., Lüschen et al. 2011, 2014). The lower Oligocene is characterized by a region of weakly developed reflections due to low impedance contrasts within the marl limestones of the Rupelian (Fig. 2). The basis of the approximately 100-150 m thick region beneath the Lithothamnium limestone is often interpreted as Purbeck or Upper Malm. Both horizons have the highest throw values compared to the hanging wall formation. A decoupling of the tectonic activity between the Lithothamnium limestone and the Lower Oligocene is therefore obvious, which is likely a result of the soft Rupelian and Chattian beds of the Oligocene (Table 1). Due to scattering within the karstified Malm carbonates reflections at the Base Malm are only poorly resolved. Reflector resolution is particularly poor beneath the major fault zones at the center of the 3D block, indicating strong scattering within the damage zone of the fault zones. However, a clear parallelism between top and base of Malm is discernible, as well as a clear contrast between Malm and the crystalline basement (Fig. 2).

Through comparison of the depth migrated seismic volume with well markers form the Unterhaching Gt 2 well, Baustein beds, Chattian, Nantesbuch sandstone, Lithothamnium limestone and top Purbeck (e.g., top Malm) were interpreted. The Baustein beds (Oligocene) are marked by a clear reflection at the transition between Lower Oligocene marlstones and compact sandstones of the Baustein beds. Within the Lower Oligocene marlstones two additional horizons were picked and interpreted ("Lower Oligocene 01" and "Lower Oligocene 02"). 


\section{Structural framework and fault zones}

Figure 3 illustrates top of the Lithothamnium limestone, its topography and most prominent structures, as already identified by Lüschen et al. $(2011,2014)$ with the nomenclature given below.

At the center of the $3 \mathrm{D}$ seismic block a $\mathrm{N} 45^{\circ} \mathrm{E}$ trending, steeply dipping normal fault is discernible which is penetrated by the Unterhaching Gt 2 well. Fault throws vary from $100 \mathrm{~m}$ in the SW to $250 \mathrm{~m}$ in the NE. The $45^{\circ}$ main fault is bounded by two faults with strike directions of $\mathrm{N} 25^{\circ} \mathrm{E}$ and $\mathrm{N} 70^{\circ} \mathrm{E}$, respectively. Throws at the $25^{\circ}$ fault are around $80 \mathrm{~m}$. The $70^{\circ}$ fault forms a system of en-echelon formal faults that are interconnected by step-over zones. Throw values are in the range of 100-180 m. These three main fault patterns merge in the SW and form a v-shaped fault block, which is internally cut and displaced by the $45^{\circ}$ main fault.

Two more fault patterns can be found in the study area, both with $70^{\circ}$ strike directions. The $70^{\circ}$ Kirchstockach fault in the $\mathrm{S}$ has throw values of up to $100 \mathrm{~m}$. The $70^{\circ}$ Unterhaching Fault is a north dipping normal fault in the NW that might extend further to the $\mathrm{W}$ and has a throw of up to $80 \mathrm{~m}$.

The $45^{\circ}$ main fault, the $70^{\circ}$ Unterhaching fault and the $70^{\circ}$ Kirchstockach fault show a clear dip direction throughout the 3D survey. However, dip directions of the $25^{\circ}$ fault and the $70^{\circ}$ en-echelon fault system were ambiguous. At most I-line sections two dip directions are discernible (e.g., I-line 162 in Fig. 2), while at some sections either a SE dip or a NW dip seems more likely.

\section{Methodology}

Two methods for the reconstruction of the kinematic evolution were applied: fault throw analysis (FTA) and structural reconstruction through horizon flattening.

\section{Fault throw analysis (FTA)}

The evolution of fault activity can be studied by comparing throw magnitudes along different horizons. Figure 4 illustrates the basic idea and approach of fault throw analysis: A normal fault develops in undisturbed rock with a throw of $10 \mathrm{~m}$. Tectonic activity stops and sedimentation begins, covering the fault entirely. In a later stage, tectonic activity starts again and the pre-existing fault is reactivated with a fault throw of $10 \mathrm{~m}$ in the upper sediments. The $10 \mathrm{~m}$ throw of the second fault activity gets added to the $10 \mathrm{~m}$ of the previous fault activity, leaving a total of $20 \mathrm{~m}$ in the base rock. One can thus analyze the tectonic activity of a fault by comparing its throw values from top to bottom.

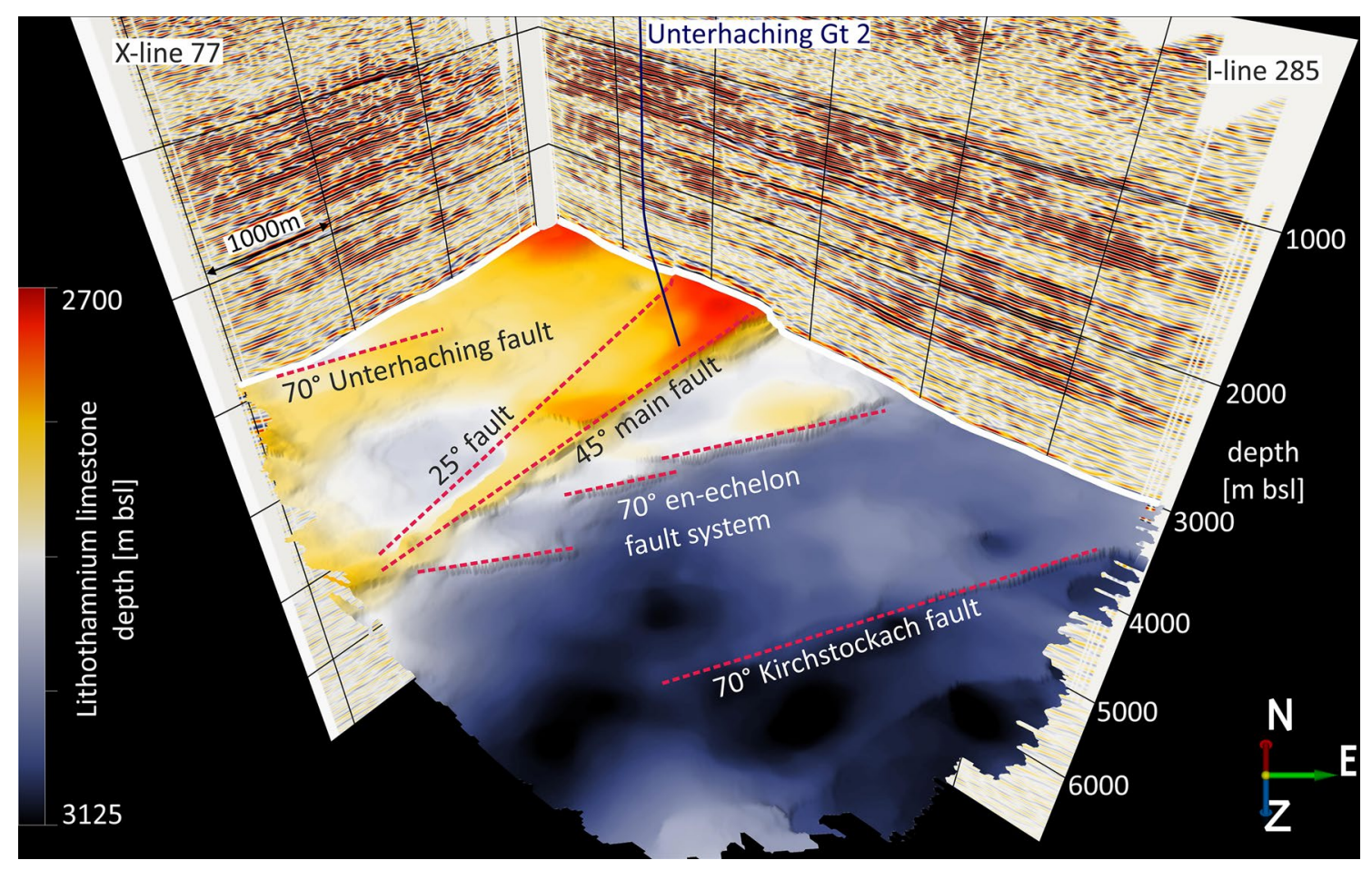

Fig. 3 Perspective view on Lithothamnium limestone showing the major faults that were analyzed in this study, well track of Unterhaching Gt 2 well is indicated as blue line. Top of Lithothamnium lime- stone interpreted after semi-automatic horizons picking. Locations of seismic sections (X-line 77 and I-line 285) shown in Fig. 1 left, no vertical exaggeration 
Fig. 4 Concept of fault throw analysis. Additional slip and continued deposition lead to thickening of strata in hanging wall blocks and consequently throw values increase from younger to older horizons, which is the pattern typical of synsedimentary normal faulting or "growth faulting"
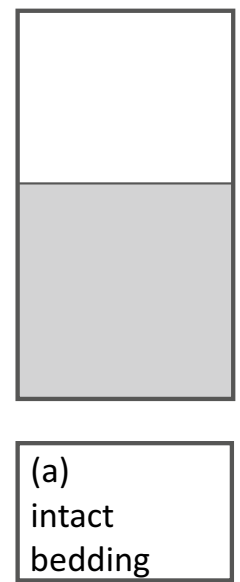

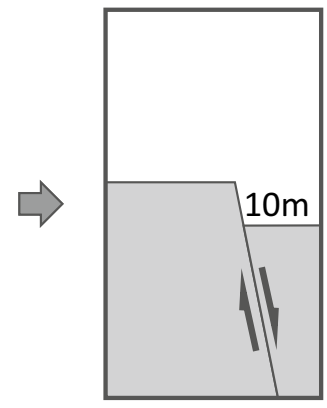

(b) fault throw of $10 \mathrm{~m}$

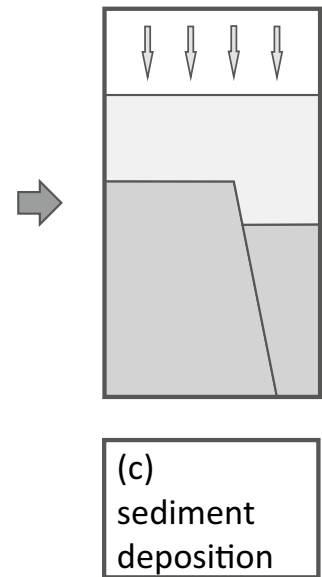

(d) fault reactivation
In practice, throw values are measured beginning with the uppermost horizon where a displacement is discernible. Then, throws are measured successively until the lowermost horizon where fault throws are visible. In a next step, the quantitative fault expansion index (QFEI) is calculated as the difference in throw between neighboring horizons. The QFEI gives information about the fault movement at a given time (e.g., during deposition of the horizon's sediments). This approach has been applied, e.g., by Moeck et al. (2015a) and Tvedt et al. (2013).

FTA at Unterhaching is illustrated in Fig. 5: while there is no displacement within the Baustein beds, a clear throw of $110 \mathrm{~m}$ is visible at the Rupelian. The same value was measured at the Lithothamnium limestone. At Turonian and Upper Malm displacement values increased to $150 \mathrm{~m}$ (Fig. 5 left).

QFEI and the cumulative fault throw are shown in Fig. 5 right. Cumulative fault throw is shown as continuous black line. Individual QFEI is indicated as grey bar plot.
The example shown in Fig. 5 indicates that the $45^{\circ}$ fault had two periods of activity between the deposition of Malm Zeta and Baustein beds: one during the Turonian (appr. 93.5-89.0 Myr) and one during the Rupelian (33.7-28.5 Myr).

\section{Structural reconstruction through horizon flattening}

Vertical displacement along faults can be easily reconstructed by the method of horizon flattening and is a standard tool in most seismic interpretation programs (Jamaludin et al. 2015).

Seismic horizons do not only contain spatial but also temporal information since they were deposited during a certain period in time (Bland et al. 2006). By means of horizon flattening, changes in formation thickness can be analyzed and one can thus obtain an insight into the deformation state of the examined horizon during the time when the flattened horizon was deposited.
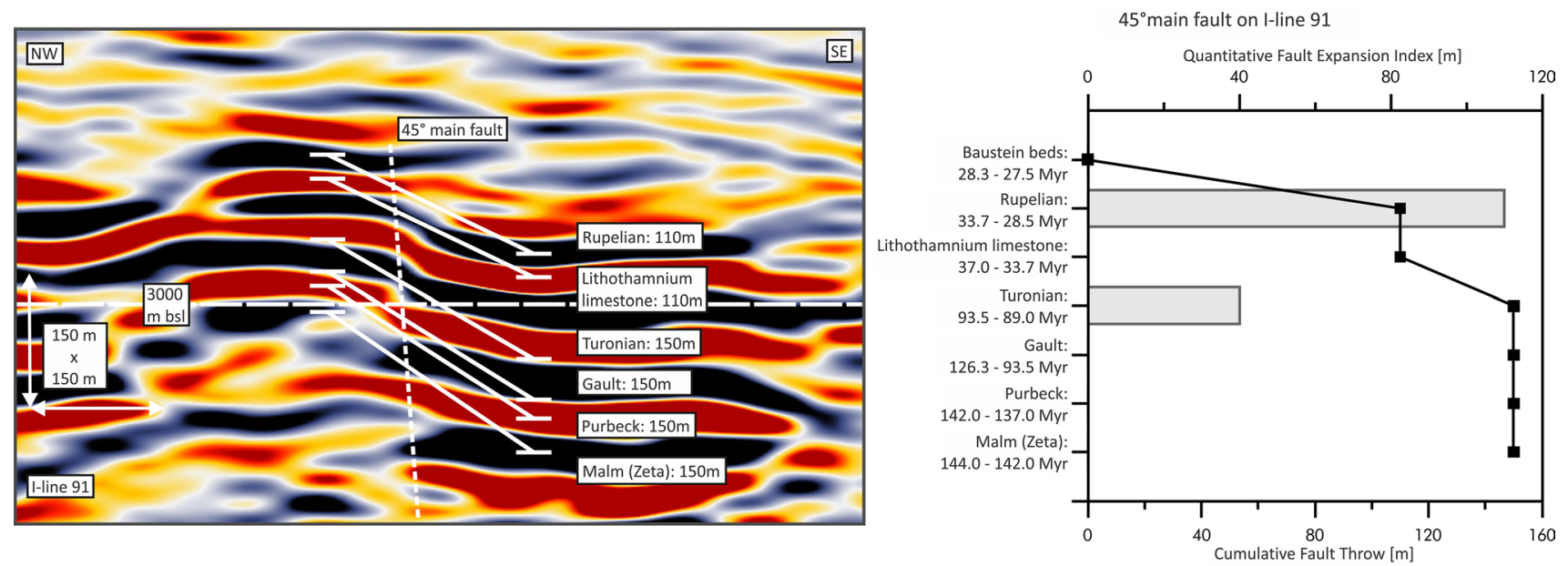

Fig. 5 Example of a fault throw analysis at the $45^{\circ}$ main fault. A clear increase in fault throws exists between Turonian and Lithothamnium limestone, indicating tectonic activity during the time of their deposition. Location of I-line 91 marked in Fig. 1, no vertical exaggeration 

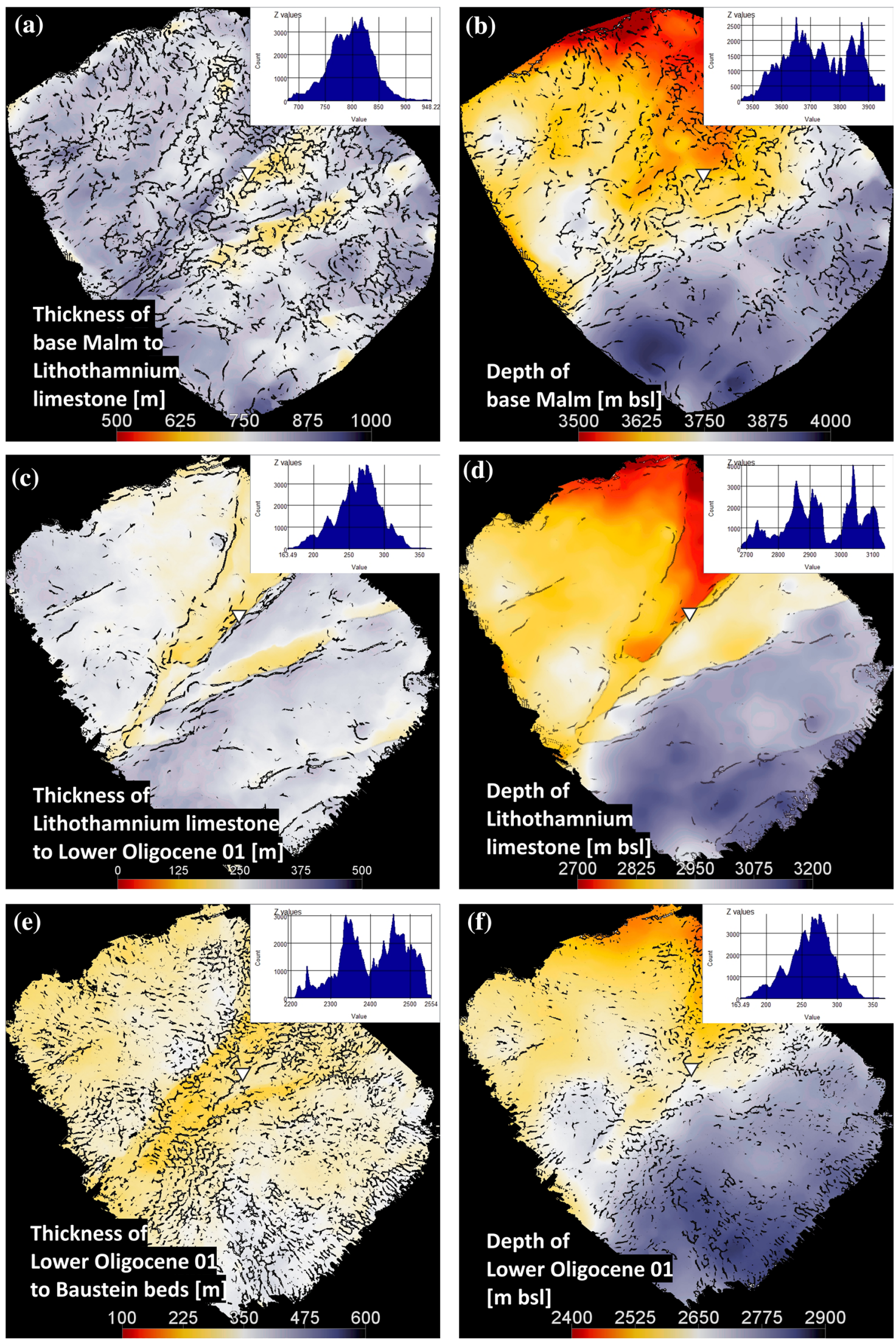
4Fig. 6 Reconstruction of tectonic activity by means of horizon flattening. a Thickness of base Malm to Lithothamnium limestone; b depth of base Malm; c thickness of Lithothamnium limestone to Lower Oligocene 01 ; d depth of Lithothamnium limestone; e thickness of Lower Oligocene 01 to Baustein beds; $\mathbf{f}$ depth of Lower Oligocene 01. Horizontal bars mark thicknesses in $\mathrm{m}$ and depth scale in $\mathrm{m} \mathrm{bsl}$, respectively. Interval for color bar is $500 \mathrm{~m}$ for all maps. Landing point of the Unterhaching Gt 2 well is indicated by a white triangle

When horizon flattening is applied, the whole seismic volume is leveled on one seismic horizon and the distance to the horizon below is analyzed. Two basic assumptions have to be considered when applying this method: (1) all observed movement was vertical and (2) the "flattened" horizon was deposited almost undisturbed.

Vertical thicknesses of strata increases within active graben systems (e.g., Tvedt et al. 2013) while the vertical thickness of strata apparently thins or completely disappears at single normal faults due to the vertical throw along normal faults (Ferrill et al. 2009). Three examples of a reconstruction through horizon flattening are shown in Fig. 6. The flattened horizons are shown on the left $(\mathrm{a}, \mathrm{c}, \mathrm{e})$, while the original-not flattened-horizons are shown on the right (b, $d, f)$. The color scales indicate thickness of lower to upper horizons and depth of the original horizon, respectively. Colors range from red (thin, shallow) to blue (thick, deep). Histograms of thickness and depth values are in the upper right corners.

\section{Results of FTA and horizon flattening}

Fault interpretation within the Malm aquifer was hindered due to the chaotic reflection pattern within the karstified carbonates. However, reconstruction of the base Malm onto the Lithothamnium limestone strongly indicates fault activity along the $70^{\circ}$ en-echelon and $45^{\circ}$ main fault patterns (Fig. 6a). Reconstruction of the Lithothamnium limestone onto the Lower Oligocene 01 suggests that the $45^{\circ}$ main fault was still active after deposition of Lithothamnium limestone sediments (Fig. 6c). Main fault activity during the deposition of Malm carbonates and the following regression/ karstification period was therefore along the $45^{\circ}$ main fault and the $70^{\circ}$ en-echelon fault. Note that the strike direction of the $70^{\circ}$ fault correlates well with the orientation of the Penninic Ocean which existed from Upper Triassic until Upper Cretaceous times.

At the end of the Mesozoic and beginning of the Tertiary fault activity at Unterhaching moved towards the N. Fault activity is documented along the $45^{\circ}$ main fault at the beginning of the Lower Oligocene. The $70^{\circ}$ trending faults are still active and later, during the Lower Oligocene, tectonic activity at the $25^{\circ}$ fault started.
FTA clearly revealed a delayed onset of activity at the $25^{\circ}$ fault. In contrast to the other analyzed faults, QFEI values $>0$ were limited to the Rupelian at the $25^{\circ}$ fault. The other faults showed activity during Rupelian and Turonian. The increase in fault throw during the Turonian (Upper Cretaceous) is in good agreement with former studies in the Southern Molasse Basin (Moeck et al. 2015a).

The common strike direction of the $70^{\circ}$ en-echelon, $70^{\circ}$ Kirchstockach and $70^{\circ}$ Unterhaching faults suggest a temporal and process-related relationship between these faults. While a simultaneous activity of the $70^{\circ}$ en-echelon and $70^{\circ}$ Kirchstockach fault is indicated by horizon flattening (Fig. 6a, c) it was not evident for the north dipping $70^{\circ}$ Unterhaching fault.

\section{Slip and dilation tendency analysis}

Horizon flattening and fault throw analysis investigate the structural evolution in the past to get insight into the presentday porosity distribution at depth. Slip tendency analysis (Morris et al. 1996; Ferrill et al. 1999), on the other hand, examines the orientation of faults within the recent stress field with the aim to delineate possible zones of enhanced permeability along fault zones. The approach used in this study follows the one presented in Moeck et al. (2009a, b).

Analysis of the slip and dilation tendency (Ferrill et al. 1999) was performed for a uniform depth of 3300 m TVD, which approximately corresponds to the center of the Malm aquifer for the most part of the 3D seismic volume.

\section{Vertical stress $\sigma_{\mathrm{V}}$}

If no measured value of the vertical stress $\sigma_{\mathrm{V}}$ is available for the desired investigation depth, the vertical stress can be calculated by integrating the rock density of the overlying rock mass over the formation thickness multiplied by the gravitational acceleration.

The corresponding density values of Molasse sediments were taken from Leu et al. (2006), density values of Malm carbonates by Homuth (2014) and formation thickness by Wolfgramm (2007).

Using these density and thickness values, the vertical stress $\sigma_{\mathrm{V}}$ at a depth of $3300 \mathrm{~m}$ was calculated as $82 \pm 4 \mathrm{MPa}$ $(82.02 \pm 4.36 \mathrm{MPa})$.

\section{Pore fluid pressure}

Experience from other geothermal wells within the South German Molasse Basin shows that the pore fluid pressure can be approximated using a fresh water density of $1 \mathrm{~g} / \mathrm{cm}^{3}$. The static water table at Unterhaching Gt 2 is $185 \mathrm{~m}$. Thus, 
for a water column of $3115 \mathrm{~m}$ the pore fluid pressure can be estimated as $31 \mathrm{MPa}$.

\section{Orientation of maximum and minimum horizontal stress}

World stress map data (Heidbach et al. 2008) provide the direction of the maximum horizontal stress $\sigma_{\mathrm{H}}$ in about $\mathrm{N}-\mathrm{S}$ direction and $\sigma_{\mathrm{h}}$ in $\mathrm{E}-\mathrm{W}$ direction mostly taken from boreholes in the Tertiary Molasse sediments and rarely in Mesozoic or deeper strata. A stress field with $\sigma_{\mathrm{H}}$ perpendicular to the mountain belt is characteristic for foreland basins as known, e.g., from the Alberta Basin (Bell and Grasby 2011; Reiter et al. 2014). Taken the ENE to WNW oriented normal faults of the Molasse Basin into account, the stress regime with $\sigma_{\mathrm{H}}$ direction in N-S may range between strike-slip faulting in deeper levels and reverse faulting in uppermost crustal levels. The presentday stress directions may contradict the observed dominated normal faults which are active until recent times at least to upper Tertiary when mountain building and foreland thrusting dominated the hinterland. More effort is therefore put on the discussion of the stress regime in the respective chapter below. Stress trajectories are plotted together with $500 \mathrm{~m}$ depth isolines of top Malm including major fault zones (Fig. 7, after Bayerischer Geothermieatlas, 2010). While the stress data is ambiguous up to $2 \mathrm{~km}$ depth, a clear alignment of horizontal stress values towards the $\mathrm{N}$ exists for greater depths.

This is supported by the stress direction shown by Reinecker et al. (2010), FMI logs at the Unterhaching Gt 2 well as well as focal mechanisms of induced seismicity at Unterhaching Gt 2 well (beach balls in Fig. 7 drawn after Megies and Wassermann 2014).

Accordingly, a strike direction of $0^{\circ}$ was chosen for the maximum horizontal stress $\sigma_{\mathrm{H}}$. The minimum horizontal stress $\sigma_{\mathrm{h}}$ strikes perpendicular to it.

\section{Magnitudes of maximum and minimum horizontal stress $\sigma_{\mathrm{H}}$ and $\sigma_{\mathrm{h}}$}

Faulted reservoirs are subject to a wide range of stress conditions. When no information on stress magnitudes is available, possible stress conditions in any crustal depth may be estimated from sliding friction considerations. The limiting assumption is that fault movement occurs when stresses exceed the frictional strength of rock referred to as frictional equilibrium (Jaeger et al. 2007). The stress state under which sliding occurs can be estimated from reasonable boundary conditions applying Anderson's faulting theory (Anderson, 1951). It is assumed that one of the principal stresses is vertical and two principal stresses are horizontal. In extensional normal faulting regimes, the horizontal stress axes are significantly smaller than the vertical stress $\left(\sigma_{\mathrm{V}}=\sigma_{1}\right)$, while in compressional regimes the opposite is true with the vertical stress significantly smaller $\left(\sigma_{\mathrm{V}}=\sigma_{3}\right)$ than the horizontal stresses. Various case studies have validated this approach in stress state estimation on borehole to reservoir scale (e.g., Peška and Zoback 1995; Nelson et al. 2007; Moeck et al. 2009a; Jolie et al. 2014). Applying these reasonable assumptions, the ratio of effective principal stresses is given by Jaeger et al. (2007):

$\frac{\left(\sigma_{1}-P_{\mathrm{F}}\right)}{\left(\sigma_{3}-P_{\mathrm{F}}\right)} \leq\left(\sqrt{\mu^{2}+1}+\mu\right)^{2}$

Here, $\sigma_{1}$ and $\sigma_{3}$ are the maximum and minimum stress directions; $P_{\mathrm{F}}$ is pore fluid pressure and $\mu$ the coefficient of sliding friction. The coefficient of sliding friction is classically referred from Byerlee (1978) who tested a variety of rocks above and below $200 \mathrm{MPa}$ for normal stress conditions resulting in a friction coefficient $\mu=0.6$ for rocks deeper than $5 \mathrm{~km}$ and $\mu=0.85$ shallower than $5 \mathrm{~km}$ depth. Byerlee's test results show already a large range of the friction coefficient for all rocks. Limestone is in the upper range of test values, partly with friction coefficients above 1 . The best estimate for the friction coefficient of the Upper Jurassic limestone of the Molasse Basin would be derived from drill cores which are rarely available. A comparable drill core is available from the Swiss Molasse Basin, in particular the Sankt Gallen geothermal well (Moeck et al. 2015b): geomechanical testing on cores from averagely $4 \mathrm{~km}$ deep Malm revealed a friction coefficient of 0.6-0.9 for different beds of the Upper Jurassic. Scuderi et al. (2013) estimated a friction coefficient of 0.75 for water saturated and hot limestone. Fault gouge hence significantly lower friction coefficients for faults is implausible for Upper Jurassic faults in the Molasse Basin since clay formations in the direct vicinity of the Upper Jurassic is lacking. Ferrill et al. (2017) argue that friction coefficients are often overestimated. In our case study, however, we refer to the drill core results from the Sankt Gallen geothermal well and assume a friction coefficient between 0.75 and 0.9 .

For $\mu=0.75$ :

$\frac{\left(\sigma_{1}-P_{\mathrm{F}}\right)}{\left(\sigma_{3}-P_{\mathrm{F}}\right)} \leq\left(\sqrt{\mu^{2}+1}+\mu\right)^{2}=4.00$,

$\sigma_{1}-P_{\mathrm{F}} \leq 4.00 \sigma_{3}-4.00 P_{\mathrm{F}}$,

$\sigma_{1}+3.00 P_{\mathrm{F}} \leq 4.00 \sigma_{3}$.

With assumed hydrostatic pore fluid pressure $P_{\mathrm{F}}=0.38 \sigma_{\mathrm{V}}$ :

$\sigma_{1}+1.14 \sigma_{\mathrm{V}} \leq 4.00 \sigma_{3}$.

For $\mu=0.9$ :

$\frac{\left(\sigma_{1}-P_{\mathrm{F}}\right)}{\left(\sigma_{3}-P_{\mathrm{F}}\right)} \leq\left(\sqrt{\mu^{2}+1}+\mu\right)^{2}=5.04$,

$\sigma_{1}-P_{\mathrm{F}} \leq 5.04 \sigma_{3}-5.04 P_{\mathrm{F}}$, 


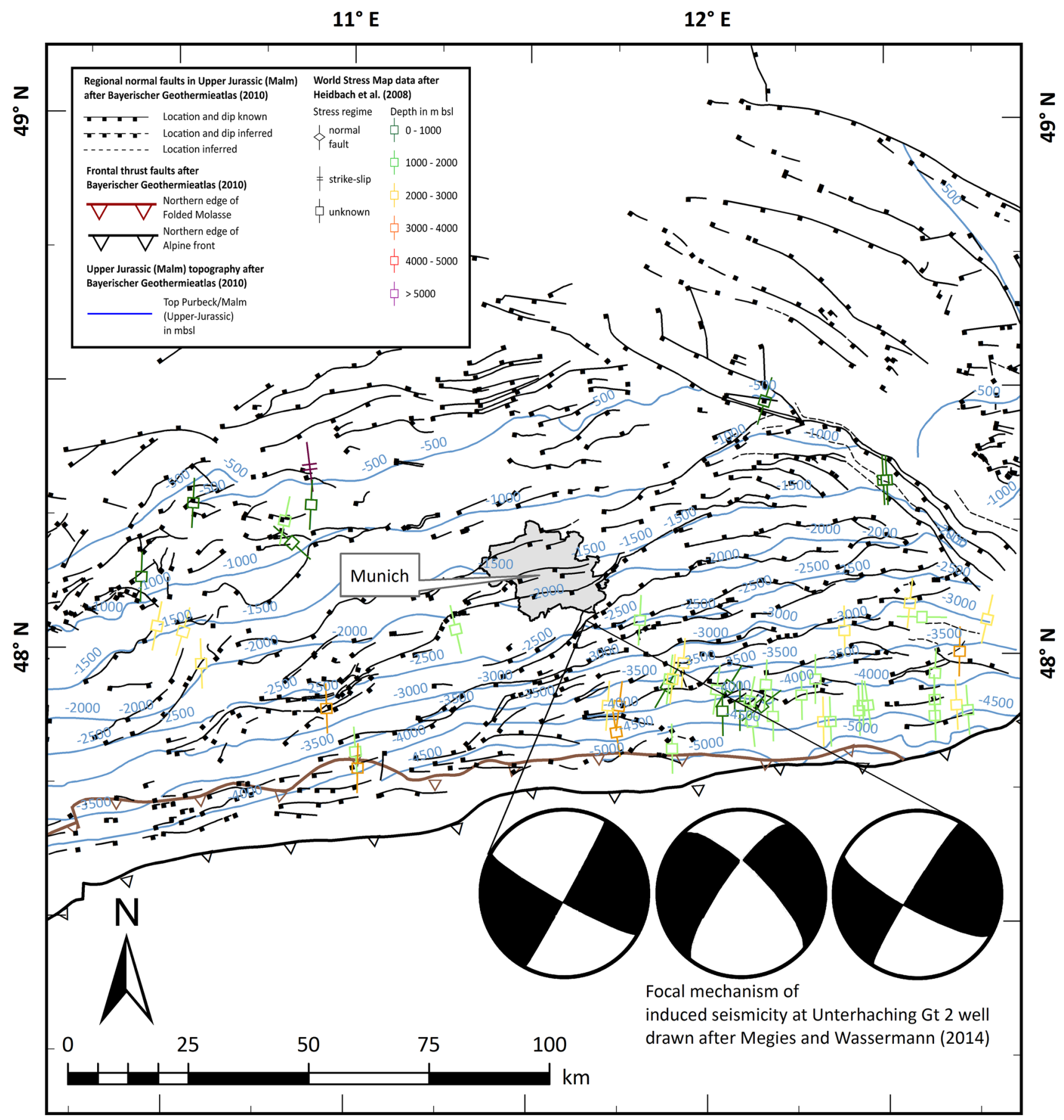

$11^{\circ} \mathrm{E}$

$12^{\circ} \mathrm{E}$

Fig. 7 Stress field map of the South German Molasse basin showing directions of the maximum horizontal stress $\sigma_{\mathrm{H}}$ as color coded symbols (after Heidbach et al. 2008); $500 \mathrm{~m}$ isolines (blue) of top Purbeck/Malm, main normal faults (black) of top Purbeck/Malm, frontal thrust faults of folded Molasse sediments and of Alpine mountain chain (modified from Bayerischer Geothermieatlas 2010); beach balls of focal mechanisms of induced seismicity at Unterhaching Gt 2 well drawn after Megies and Wassermann (2014). Note the alignment of $\sigma_{\mathrm{H}}$ into a common direction of approximately $0^{\circ}$ for depths below top Malm. Location of stress field map shown in overview map in Fig. 1 right 
$\sigma_{1}+4.04 P_{\mathrm{F}} \leq 5.04 \sigma_{3}$.

With assumed hydrostatic pore fluid pressure $P_{\mathrm{F}}=0.38$ $\sigma_{\mathrm{V}}$ :

$\sigma_{1}+1.54 \sigma_{\mathrm{V}} \leq 5.04 \sigma_{3}$

These calculations define the stress ratios of the maximum and the minimum principal stresses to the vertical stress for a given friction coefficient and pore fluid pressure (Moeck et al. 2009a). With that result, it is possible to calculate the bounding stress ratio for reverse and for normal faulting, assuming Anderson's faulting theory (1951). In a reverse faulting regime with $\sigma_{\mathrm{V}}=\sigma_{3}$ and a friction coefficient $\mu=0.75$ the upper limiting ratio is:

$\sigma_{\mathrm{H} \text { max }} \leq 2.87 \sigma_{\mathrm{V}}$.

In a normal faulting regime with $\sigma_{\mathrm{V}}=\sigma_{1}$ and a friction coefficient $\mu=0.75$ the lower limiting ratio is:

$\sigma_{\mathrm{h}_{\min }} \geq 0.53 \sigma_{\mathrm{V}}$.

The maximum and minimum magnitudes for the horizontal stresses ranging from reverse to normal faulting can be determined for a given reservoir depth. Representative for the Unterhaching reservoir depth, the vertical stress is $\sigma_{\mathrm{V}}=82 \pm 4 \mathrm{MPa}$, resulting in the maximum possible stress magnitude for $\sigma_{\mathrm{H}}=\sigma_{1}$ in a reverse faulting stress regime:

$\sigma_{\mathrm{H} \text { max }}=253 \pm 11 \mathrm{MPa}$,

and the minimum magnitude for the horizontal stress, now in a normal faulting stress regime with $\sigma_{\mathrm{h}}=\sigma_{3}$ :

$\sigma_{\mathrm{h}_{\text {min }}}=43 \pm 2 \mathrm{MPa}$.

In a reverse faulting regime with $\sigma_{\mathrm{V}}=\sigma_{3}$ and a friction $\mu=0.9$ the upper limiting ratio is:

$\sigma_{\mathrm{H} \max } \leq 3.51 \sigma_{\mathrm{V}}$

In a normal faulting regime with $\sigma_{\mathrm{V}}=\sigma_{1}$ and a friction coefficient $\mu=0.75$ the lower limiting ratio is:

$\sigma_{\mathrm{h}_{\min }} \geq 0.50 \sigma_{\mathrm{v}}$.

Representative for the Unterhaching reservoir depth, with the vertical stress is $\sigma_{\mathrm{V}}=82 \pm 4 \mathrm{MPa}$, resulting in the maximum possible stress magnitude for $\sigma_{\mathrm{H}}=\sigma_{1}$ in a reverse faulting stress regime:

$\sigma_{\mathrm{H} \text { max }}=288 \pm 14 \mathrm{MPa}$,

and the minimum magnitude for the horizontal stress, now in a normal faulting stress regime with $\sigma_{\mathrm{h}}=\sigma_{3}$ :

$\sigma_{\mathrm{h}_{\text {min }}}=41 \pm 2 \mathrm{MPa}$
The range of possible stress values can be illustrated graphically by stress polygons (e.g., Zoback et al. 2003; Moeck et al. 2009a).

Figure 8 shows the stress polygon for the Unterhaching reservoir in the Upper Jurassic (3300 m) depth for both friction coefficients. The range of possible values for the minimum horizontal stress $\sigma_{\mathrm{h}}$ min is shown on the $x$-axis, the possible values of the maximum horizontal stress $\sigma_{\mathrm{H} \text { max }}$ is shown on the $y$-axis. The position of the diagonal line defines the vertical stress $\sigma_{\mathrm{V}}$. Since $\sigma_{\mathrm{H} \text { max }}$ is always greater than or equal to $\sigma_{\mathrm{h}}$ min , all possible stress states are above the $\sigma_{\mathrm{V}}$-diagonal line.

\section{Stress regime}

Reinecker et al. (2010) suggest in their World Stress Map data analysis a reverse to strike slip faulting regime for the present day stress field of the Western Molasse basin. Most of Reinecker's et al. (2010) analyzed borehole data are however from Tertiary sediments and do not necessarily reflect the stress regime in the Mesozoic strata. The majority of interpreted normal faults in seismic data are striking in ENE to WNW indicating a normal faulting stress regime with $\sigma_{\mathrm{h}}=\sigma_{3}$ in NNW to NNE. This normal faulting stress regime contradicts the observed borehole breakout data of Reinecker et al. (2010) with $\sigma_{\mathrm{H}}$ in $\mathrm{N}-\mathrm{S}$ in a reverse to strike slip faulting regime. Moeck et al. (2015a) pointed out the contrasting present-day stress and the observed faulting regime. ENE to WNW striking normal faults in the Molasse basin were active at least until the Lower Miocene (Burdigal) (Moeck et al. 2015a; Cacace et al. 2013) indicating $\sigma_{\mathrm{h}}=\sigma_{3}$ in $\mathrm{N}-\mathrm{S}$ direction during foreland basin formation throughout the Tertiary. Possibly the multiphase activity of normal faulting resulted from lithospheric bending and extension perpendicular to the evolving mountain belt as known from collisional foredeeps (e.g., Bradley and Kidd 1991). Obviously, at the end of Tertiary or transition to Quaternary the stress tensor rotated around the vertical stress axis resulting in a switch of $\sigma_{3}$ from $\mathrm{N}-\mathrm{S}$ to $\mathrm{E}-\mathrm{W}$. Contemporarily the vertical stress $\sigma_{\mathrm{V}}=\sigma_{1}$ decreased compared to $\sigma_{\mathrm{H}}=\sigma_{2}$ suggesting similar magnitudes of $\sigma_{2}$ and $\sigma_{1}$. The importance of the intermediate stress axis for fault reactivation and stress field determination is described by Morris and Ferrill (2009) describing fault activation along non-optimally oriented faults under varying intermediate stresses. The change of $\sigma_{\mathrm{H}}$ from formerly $\sigma_{2}$ to $\sigma_{1}$ today could be caused be the increasing compressional stresses from the collisional zone in the Alpine chain. We suggest therefore a strike slip to normal faulting stress regime in the Mesozoic Upper Jurassic strata. 
Fig. 8 Stress diagram for the Malm at Unterhaching showing two possible scenarios for coefficients of sliding friction of 0.75 and 0.9 and a depth of $3300 \mathrm{~m}$ TVD

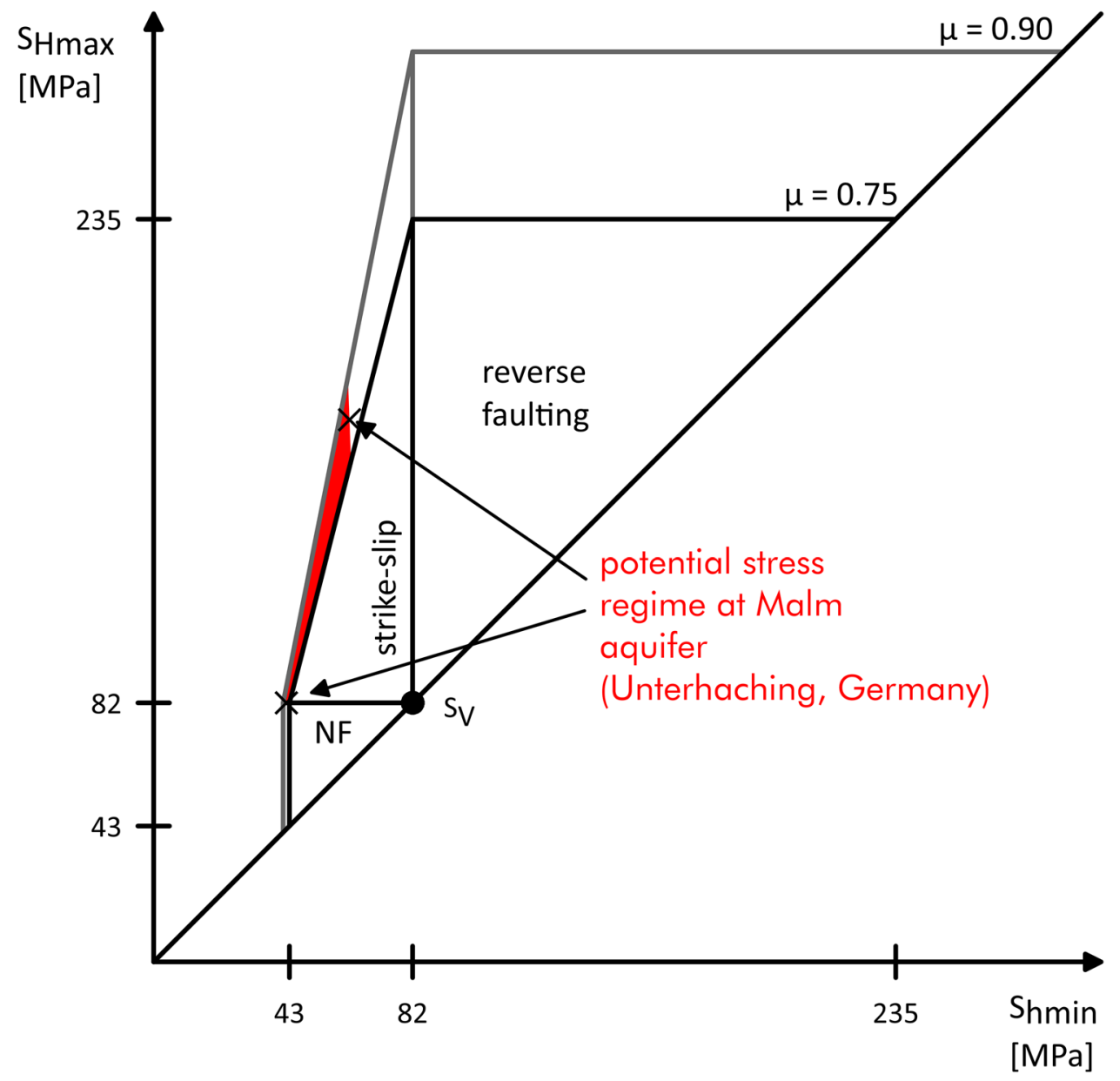

The strike-slip stress field is verified by recorded seismic events in the Unterhaching geothermal field in 2008. Focal mechanisms calculated for three microseismic events (Megies and Wassermann 2014) reveal a predominant strikeslip regime with a left-lateral motion at fault planes between the $25^{\circ}$ and the $45^{\circ}$ main fault and with a slight oblique dip towards normal faulting. $\sigma_{\mathrm{H}}=\sigma_{1}$ is striking in N-S while $\sigma_{\mathrm{h}}=\sigma_{3}$ is striking in E-W. The slip and dilation tendency is therefore calculated for both a strike-slip faulting and a transtensional strike-slip to normal faulting stress regime with $\sigma_{\mathrm{H}}=\sigma_{1}$ in $\mathrm{N}-\mathrm{S}$ direction.

\section{Slip and dilation tendency}

The stress magnitudes and directions described above are used to calculate the tendency of faults to slip and to dilate. The maximum slip tendency is the maximum ratio of shear to normal stress while the dilation tendency considers the ratio of differential stress between $\sigma_{1}$ and normal stress to $\sigma_{1}$ and $\sigma_{3}$. Effectively, maximum dilation tendency is reached when the normal stress equals $\sigma_{3}$ acting on a fault plane (Ferrill et al. 1999).
Results of this analysis are shown in Fig. 9 for both strike slip to normal faulting and for pure strike slip faulting. Slip and dilation tendency is illustrated in the lower hemisphere projection, the slip tendency distribution is transferred to the planes of the five investigated faults documenting the NNE to NE striking fault segments with maximum slip tendency in red to orange colors. The color scale indicates low slip tendencies (blue) to high slip tendencies (red). In general, slip tendency of a fault within these stress fields is controlled by its orientation to the present-day stress tensor. Gently dipping faults have low resolved shear stress and relatively high normal stress, and consequently low slip tendency independent of their strike direction. With increasing dip angle, the strike direction becomes more important. NE to $\mathrm{N}-\mathrm{S}$ to $\mathrm{NW}$ striking faults with dip angles between $20^{\circ}$ and $40^{\circ}$ to the West or East have the highest slip tendency in a transitional stress field from strike-slip to normal faulting. Probably, these segments are close to slip and could be most likely reactivated under fluid injection which decreases the normal stress (Moeck et al. 2009a). Induced seismicity would be likely assuming this concept of effective stresses. In 
Strike slip to normal faulting: $\sigma_{\mathrm{V}}=82 \mathrm{MPa}, \sigma_{\mathrm{H} \max }=82 \mathrm{MPa}, \sigma_{\mathrm{hmin}}=42 \mathrm{MPa}, \mathrm{P}_{\mathrm{F}}=31 \mathrm{Mpa}$
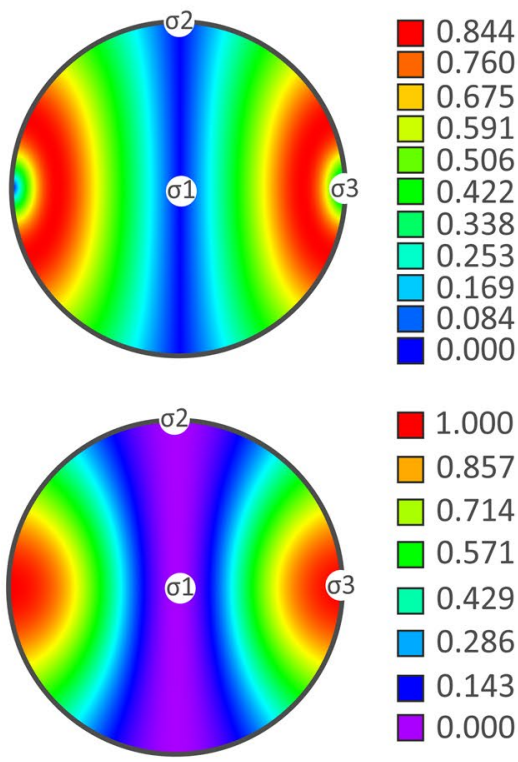

0.286

0.143

0.000
1.000

0.857

0.714 dilation tendency

$0.571 \quad \frac{\left(\sigma_{1}-\sigma_{n}\right)}{\left(\sigma_{1}-\sigma_{3}\right)}$
Slip tendency on fault planes

slip tendency

$$
\frac{\tau}{\sigma_{n}}
$$

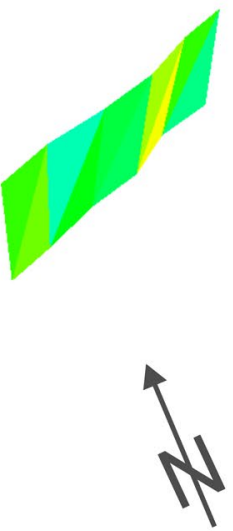

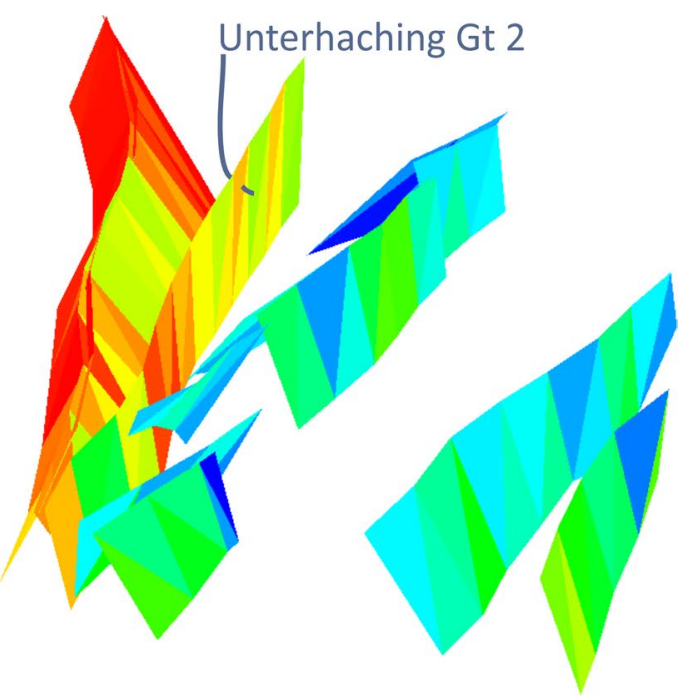

Strike slip faulting: $\sigma_{\mathrm{V}}=82 \mathrm{MPa}, \sigma_{\mathrm{H} \max }=172 \mathrm{MPa}, \sigma_{\mathrm{hmin}}=62 \mathrm{MPa}, \mathrm{P}_{\mathrm{F}}=31 \mathrm{MPa}$

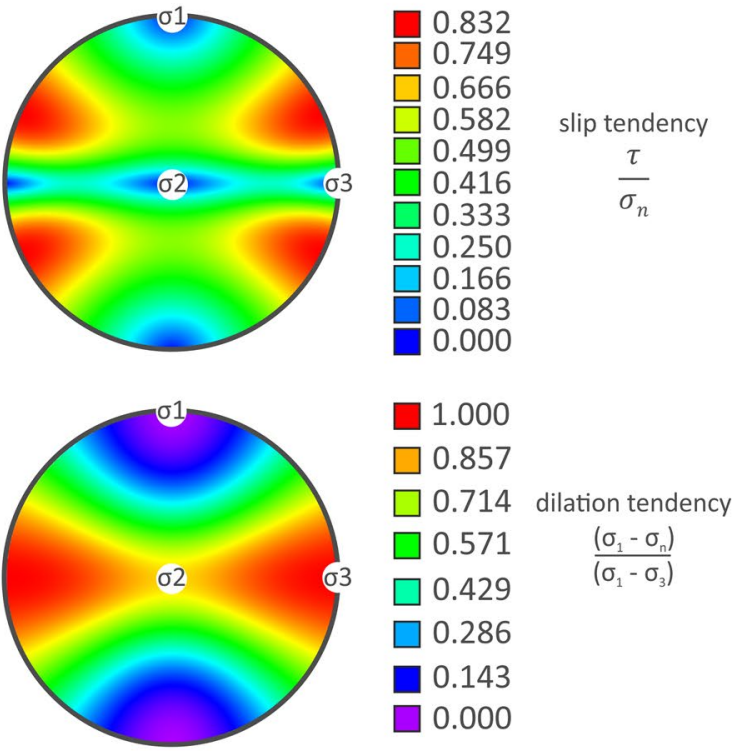

Fig. 9 Slip and dilation tendency for a strike slip to normal faulting regime (top) and a pure strike slip faulting regime (bottom). The main faults of the Unterhaching 3D seismic survey (Fig. 3) are shown on
Slip tendency on fault planes
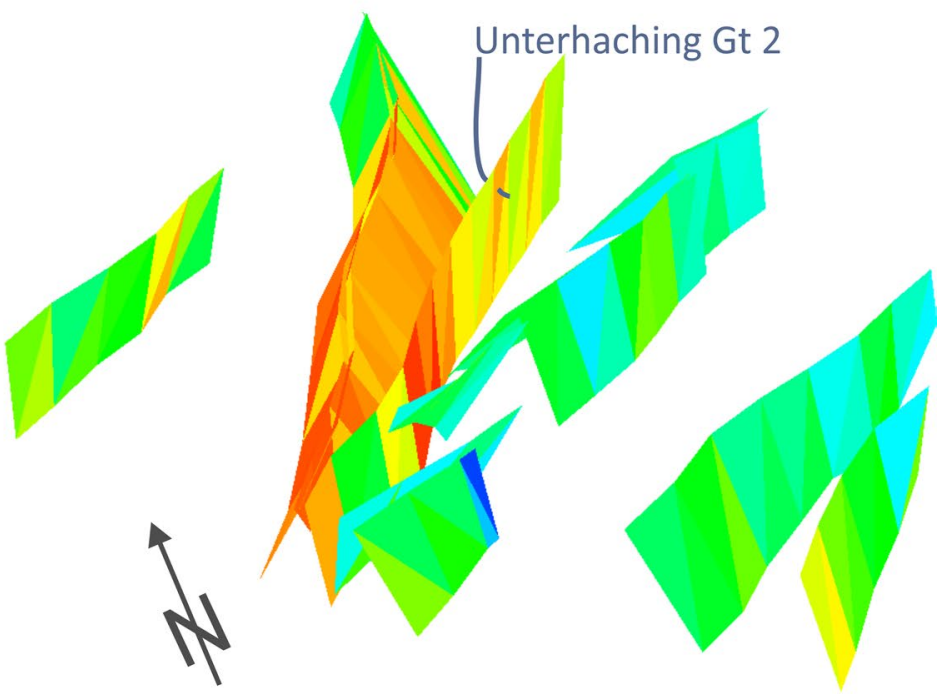

a strike-slip stress regime with an intermediate principal stress magnitude significantly lower than the maximum principal stress magnitude, the highest slip tendency is located along NE and NW striking faults with steep dip to $35^{\circ}$ to the East or West. Dilation tendency is maximum the right and are colored according to their slip tendency. The highest slip tendency is observed at the $25^{\circ}$ fault and $45^{\circ}$ main fault, independent of the assumed stress regime at NNE to N-S to NNW striking vertically to steeply dipping faults (Fig. 9). The productive geothermal well Gt Unterhaching 2 is placed into a fault segment with high but not maximum dilation and slip tendency in both stress regimes. 
In particular, high slip tendency is attributed to the $25^{\circ}$ fault and intermediate to high values to the $45^{\circ}$ main fault. The $70^{\circ}$ striking faults are non-optimally oriented in the present-day stress field and have comparably low slip tendencies.

Differences between the examined cases exist in the absolute as well as in the relative slip tendency values. While slip tendency is higher for the strike slip regime at the $70^{\circ}$ striking faults, it is lower at the $25^{\circ}$ fault and the $45^{\circ}$ main fault. For the normal faulting to strike slip regime, the range of possible slip tendency values are higher than the regime with pure strike slip.

Additionally, the possibility of a pure normal faulting regime was tested. The analysis revealed very low slip tendency values at the $45^{\circ}$ main fault around the Gt Unterhaching 2 reinjection well. However, injectivity is high in the Gt Unterhaching 2 well, and at least deeper parts of the $45^{\circ}$ main fault were reactivated due to reinjection of thermal water into the well indicating high permeability, consistent with high slip tendency. Therefore, a normal faulting stress regime and its resulting low slip tendency seems unlikely for the $45^{\circ}$ main fault. This indicates that a pure normal fault regime has a low probability and that the actual stress regime in the Malm at Unterhaching is at least in the transition to strike slip faulting.

A transitional stress regime between normal faulting to strike slip faulting is further supported by focal mechanisms of seismicity recorded from the $45^{\circ}$ main fault [cf. beach balls of focal mechanism drawn after Megies and Wassermann (2014) in Fig. 7]. Slip tendency suggests only for a transitional stress regime a highly critical stress state of both the $45^{\circ}$ main fault and the $25^{\circ}$ fault (red colored fault planes in Fig. 9 top). In a strike-slip stress regime the slip tendency is lower along both faults.

\section{Discussion}

\section{Kinematic models}

The characteristic v-shaped fault block between the $25^{\circ}$ fault and the $70^{\circ}$ en-echelon fault system (Fig. 3) and the ambiguous dip directions of the two faults confining this fault block (Fig. 2) led to the development of two kinematic models for the structural evolution of the Malm aquifer at Unterhaching (Fig. 10). Both of them independently explain the formation of the $\mathrm{v}$-shaped horst structure in the center of the study area. Scenario A assumes a positive flower structure and scenario B conjugate crossing normal faults (e.g., Ferrill et al. 2000, 2009) to be the major factor of the structural evolution.

Note that elements of both models might have contributed to the structural evolution at Unterhaching.
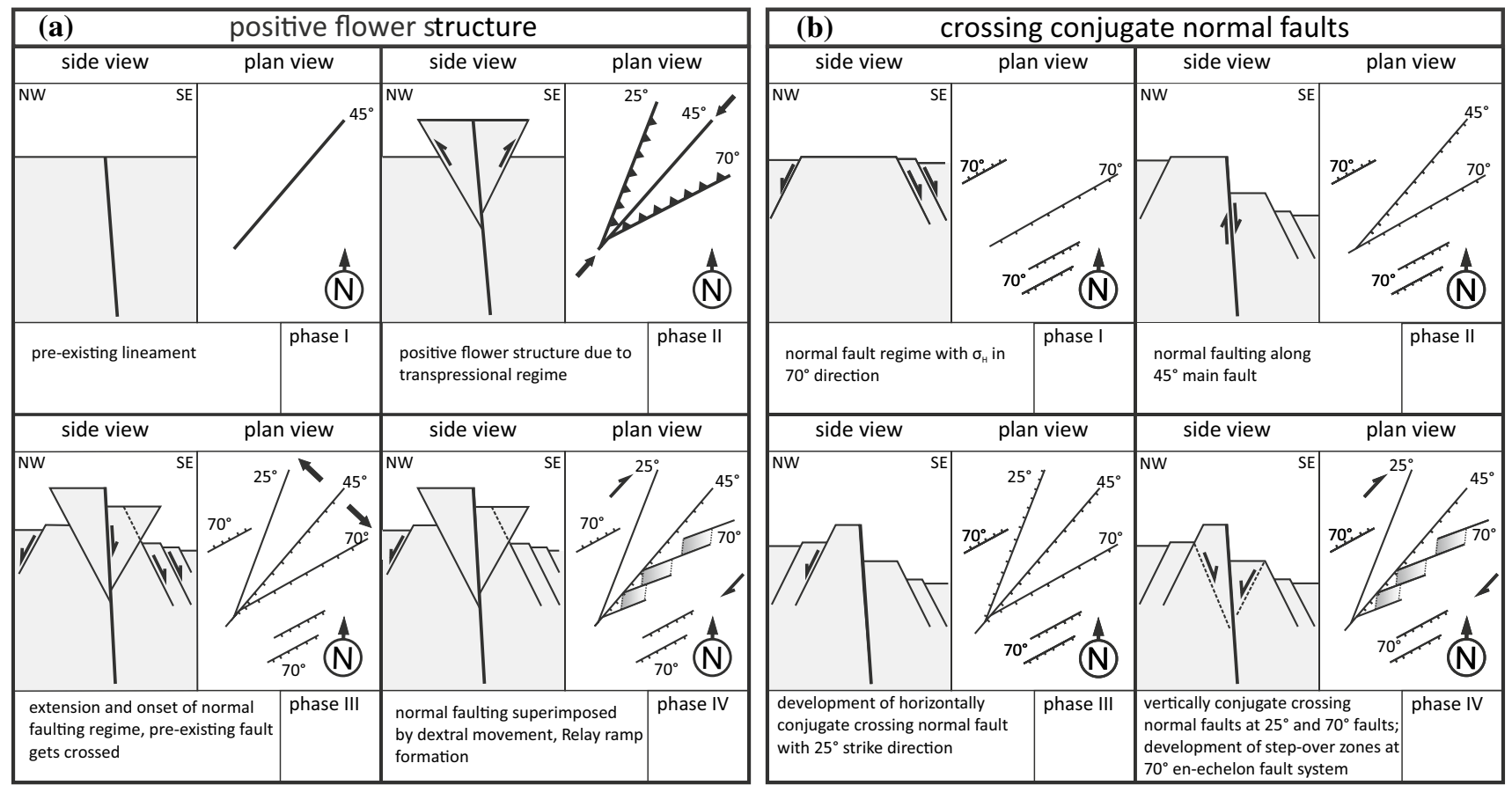

Fig. 10 Kinematic models explaining the structural evolution of the Malm at Unterhaching: a positive flower structure, b crossing conjugate normal faults 


\section{Hypothesis A Positive flower structure.}

The characteristic v-shaped pop-up structure could have been developed as a positive flower structure along a convergent strike-slip zone. These structures can form complex bivergent normal fault pattern in cross sections perpendicular to the strike-slip, which resemble flower shapes (Eisbacher 1991). A possible kinematic evolution could incorporate four stages (Fig. 10 left).

Stage 1 A lineament pre-existed at the location of today's $45^{\circ}$ main fault. The lineament could have been formed during the opening of the Penninic Ocean some $165 \mathrm{Myr}$ ago (Schuster and Stüwe 2010).

Stage 2 The collision of the African and European Plates during the late Cretaceous resulted in a transpressional regime. The transpression let to the formation of a positive flower structure along the pre-existing lineament. During this stage the prominent $v$-shaped horst structure as well as $25^{\circ}$ and $70^{\circ}$ en-echelon faults were formed.

Stage 3 The lithospheric load through increasing overburden containing Molasse sediments increased with the ongoing collision of both continents, subsequent rise and erosion of and sedimentation from the Alps. This led to a change in the tectonic regime from a transpressional to a normal fault regime, which caused the formation of the $70^{\circ}$ Unterhaching and $70^{\circ}$ Kirchstockach faults in the NW and SE, respectively. The whole southeastern block was displaced along the $45^{\circ}$ main fault and conjugate normal faults formed along the other existing faults.

Stage 4 With the ongoing Alpine orogeny, a local dextral strike-slip regime formed. This resulted in a break-off of the $70^{\circ}$ en-echelon fault into several smaller fault segments connected via step-over zone or relay ramps, respectively.

\section{Hypothesis B Conjugate, crossing normal faults.}

The prominent v-shaped horst structure could also be explained by conjugate crossing normal faults. These are common features of normal faulting dominated sedimentary basins and consist of two normal faults with opposite dip direction (Ferrill et al. 2009). If the two normal faults have different strike directions, they can form a v-shaped horst structure like the one found at Unterhaching. A possible kinematic evolution could incorporate four stages:

Stage 1 A normal fault regime existed with the maximum horizontal stress $\sigma_{\mathrm{H}}$ oriented in $70^{\circ}$ direction and $\sigma_{\mathrm{h}}$ in $160^{\circ}$ direction leading to the formation of the $70^{\circ}$ trending normal faults $\left(70^{\circ}\right.$ main fault, $70^{\circ}$ Unterhaching fault, $70^{\circ}$ Kirchstockach fault).

Stage 2 The direction of $\sigma_{\mathrm{H}}$ and $\sigma_{\mathrm{h}}$ rotated counter-clockwise and the $45^{\circ}$ main fault developed. Existing faults might have been reactivated during that time as oblique normal faults.
Stage 3 The $25^{\circ}$ fault developed as a conjugate crossing normal fault to the $70^{\circ}$ en-echelon fault, thus forming the prominent v-shaped horst structure.

Stage 4 The normal faulting regime is superimposed by a strike-slip component at the end of the structural evolution which led to the formation of step-over zones at the $70^{\circ}$ enechelon fault. Later, ongoing normal fault activity resulted in the formation of conjugate crossing normal faults along existing fault zones.

\section{Evaluation of kinematic models}

FTA and horizon flattening clearly indicate a non-simultaneous fault activity at Unterhaching, which supports the model of crossing normal faults. Theoretically, the $25^{\circ}$ and $70^{\circ}$ en-echelon fault should have been active at the same time in order to form a positive flower structure. FTA and horizon flattening indicate, however, that the $25^{\circ}$ fault was active later than the other faults. The sequential formation of faults supports the conjugate normal faulting concept rather than the positive flower structure concept. More indications for the crossing normal fault concept are bed thinning, damage zone intensification and attenuation (Ferrill et al. 2009). The seismic data of the Unterhaching prospect do not further reveal clear indications. The bed thickness of the Malm formation of $600-650 \mathrm{~m}$ is significantly larger than the cumulative fault throw of maximum $200 \mathrm{~m}$. Approaching the crossing faults, the base Malm reflector cannot be clearly identified. Hence bed thickness remains unclear especially in fault zone areas where seismic reflectors weaken or disappear. An indirect indication might be the intensification of the damage zone in the Malm carbonate rocks which is supposedly a brittle competent rock (Table 1) supporting higher fracture densities (Ferrill et al. 2009). The high fracture density could explain the increased reservoir permeability and consequently the productivity of the Unterhaching Gt 2 well which is drilled in the $45^{\circ}$ fault zone.

\section{Position of the faults in the present stress field and its relevance for geothermal exploration}

The analysis of the temporal evolution of fault zones is important for two reasons: (1) faults that were active during the Jurassic regression of the Tethys Ocean have a higher probability to be karstified and (2) faults that were active over longer periods of time have a lower probability to be healed.

The Tethys Ocean faced a major regression period during the Lower Cretaceous and most parts of the Molasse Basin fall dry. The hot and wet tropical climate during that time led to intensive karstification within the exposed Malm carbonates (Bachmann et al. 1987). One can expect the karstification to be most effective along existing fault zones. These 
regions of enhanced primary karstification should also have enhanced (secondary) karstification and therefore a lower exploration risk compared to the surrounding rocks.

Through compaction and mineral precipitation permeability within a fault zone might decrease over time, the fault zone "heals". If the fault zone is episodically active over time, this healing process can be interrupted or already healed parts can be opened again, which would also result in enhanced permeability. Accordingly, the exploration risk is reduced in these regions.

Apart from their kinematic evolution it is also important to analyze the fault orientation within the present-day stress field. Faults with an angle of $20^{\circ}-45^{\circ}$ with respect to the maximum horizontal stress $\sigma_{\mathrm{H}}$ have a higher slip tendency and thus a higher probability to be reactivated. Furthermore, the fault permeability can be enhanced due to the formation of secondary shear fractures during episodic fault slip. Ultimately, stress field analysis should be a standard method in geothermal exploration (e.g., Moeck et al. 2009a).

The present-day stress field in the study area has a preferred orientation of $\sigma_{\mathrm{H}}$ of approximately $0^{\circ}$ (Megies and Wassermann 2014; Reinecker et al. 2010). Referring to the potential of faults to dilate, the $25^{\circ}$ fault should have an enhanced dilation tendency and therefore possibly higher permeability provided that faults occur in competent (brittle) rock.

\section{Conclusion}

The structural evolution of the Malm aquifer at Unterhaching (Germany) was analyzed using 3D seismic data and two kinematic models were presented that could explain the observed structures. One model assumes a positive flower structure, the other one crossing normal faults.

In order to verify both models, two methods were applied that allow insight into the temporal evolution of fault systems: (1) structural reconstruction through horizon flattening and (2) fault throw analysis.

The results indicate a multiphase activity of the faults at different periods. Tectonic activity started during the Jurassic along the $70^{\circ}$ trending faults and shifted towards $45^{\circ}$ trending faults (Cretaceous) and later to $25^{\circ}$ trending faults (Early Tertiary). This observation prefers for the model of large scale crossing normal faulting because a positive flower structure would incorporate faults that were simultaneously active. A system of crossing normal faults would result in the formation of a $\mathrm{v}$-shaped graben, juxaposed to the v-shaped horst structure. Unfortunately, this remains a speculation due to a lack of seismic data West of the study area. Future seismic measurements SW of Unterhaching could test this hypothesis and could help to improve the kinematic model.
The investigated structure is in the Upper Jurassic Malm aquifer, a carbonate reservoir utilized for geothermal production. A key aspect for productive wells is to drill into structures with enhanced permeability. The kinematic analysis of faults may help to identify the individual zones of cumulative permeability increase particularly for the Molasse basin:

- Crossing normal faults contain an elevated number of intersection lines serving as preferred channels for fluids even along non-optimally oriented faults with respect to the present-day stress field.

- Recognizing the fault activity phases in carbonate rock is important when correlated to regression or uplift associated with karstification: only faults in the Upper Jurassic active during regression and exposure might be maximally karstified and may serve as optimal fluid pathways.

- Faults with multiphase activity might be jacketed with an intensively fractured damage zone hence high permeability zone resulting from periodic fault slip and formation of secondary fractures.

- The productive geothermal Gt 2 well in the Unterhaching field is drilled into a fault segment with elevated slip and dilation tendency suggesting both slip and dilation are important for enhanced permeability of faults hence productivity of wells.

Structural reconstruction, fault displacement analysis and stress state determination of fault planes in the present-day stress field help to better understand fault evolution in foreland basins. Moreover, the gathered knowledge about the temporal evolution of a fault system can help to minimize the exploration risk for production wells. The methodology in fault analysis was applied on an individual fault zone in the Unterhaching field south of Munich. A better understanding about subsurface fault zone evolution in foreland basins and their permeability structure could be achieved if the presented methodology would be applied on a regional scale.

Acknowledgements This research was performed as part of the joint research project "Malm Facies", funded by the German Federal Ministry for Economic Affairs and Energy (BWMi), grant no. 41V6577. Seismic data were kindly provided by the Leibniz Institute for Applied Geophysics (LIAG). Seismic interpretation was done using the open source seismic interpretation platform OpendTect by dGB Earth Sciences. Slip and dilation tendency was analyzed and imaged applying 3DStress software by Southwest Research Institute. We thank David A. Ferrill and an anonymous reviewer for their detailed reviews that helped to significantly improve the manuscript.

Open Access This article is distributed under the terms of the Creative Commons Attribution 4.0 International License (http://creativecommons.org/licenses/by/4.0/), which permits unrestricted use, distribution, and reproduction in any medium, provided you give appropriate credit to the original author(s) and the source, provide a link to the Creative Commons license, and indicate if changes were made. 


\section{References}

Anderson EM (1951) The dynamics of faulting and dyke formation with application to Britain. Oliver and Boyd, Edinburgh

Bachmann GH, Müller M (1992) Sedimentary and structural evolution of the German Molasse Basin. Eclogae Geol Helv 85(3):519-530

Bachmann GH, Müller M, Wegen K (1987) Evolution of the Molasse Basin (Germany, Switzerland). Tectonophysics 137:77-92

Bell S, Grasby SE (2011) The stress regime of the Western Canadian Sedimentary Basin. Geofluids 12(2):150-165

Bland S, Griffiths P, Hodge D, Ravaglia A (2006) Restoring the seismic image. Geohorizons 11(1):18-23

Blisnuik PM, Sonder LJ, Lillie RJ (1998) Foreland normal fault control on the northwest Himalayan thrust front development. Tectonics 17(5):766-779

Bradley DC, Kidd WSF (1991) Flexural extension of the upper continental crust in collisional foredeeps. GSA Bull 103:1416-1438

Byerlee JD (1978) Friction of rocks. Pure Appl Geophys 116:615-626

Cacace M, Bloecher G, Watanabe N, Moeck I, Boersing N, ScheckWenderoth M, Kolditz O, Huenges E (2013) Modelling of fractured carbonate reservoirs: outline of a novel technique via a case study from the Molasse Basin, southern Bavaria, Germany. Environ Earth Sci 70(8):3585-3602. doi:10.1007/s12665-013-2402-3

Casini M, Ciuffi S, Fiordelisi A, Mazzotti A, Stucchi E (2010) Results of a 3D seismic survey at the Travale (Italy) test site. Geothermics 39:4-12

Dussel M, Lüschen E, Thomas R, Agemar T, Fritzer T, Sieblitz S, Huber B, Birner J, Schulz R (2016) Forecast for thermal water use from Upper Jurassic carbonates in the Munich region (South German Molasse Basin). Geothermics 60:1330. doi:10.1016/j. geothermics.2015.10.010

Eisbacher GH (1991) Einführung in die Tektonik. Ferdinand Enke Verlag Stuttgart, Stuttgart

Ferrill DA, Winterle J, Wittmeyer G, Sims D, Colton S, Armstrong A, Morris AP (1999) Stressed rock strains groundwater at Yucca Mountain, Nevada. GSA Today 9(5):1-8

Ferrill DA, Morris AP, Stamatakos JA, Sims D (2000) Crossing conjugate normal faults. AAPG Bull 84(10):1543-1559

Ferrill DA, Morris AP, Mc Ginnis RN (2009) Crossing conjugate normal faults in field exposures and seismic data. AAPG Bull 93(11):1471-1488

Ferrill DA, Morris AP, McGinnis RN, Smart KJ, Wigginton SS, Hill NJ (2017) Mechanical stratigraphy and normal faulting. J Struct Geol. doi:10.1016/j.jsg.2016.11.010

Freudenberger W, Schwerd K (1996) Erläuterungen zur Geologischen Karte von Bayern 1:500,000.- 4. Auflage. Bayerisches Geologisches Landesamt, München

Geothermieatlas Bayerischer (2010) Bayerischer GeothermieatlasHydrothermale Energiegewinnung Bayerisches Staatsministerium für Wirtschaft. Infrastruktur, Verkehr und Technologie, München, p 93

Heidbach O, Tingay M, Barth A, Reinecker J, Kurfeß D, Müller B (2008) The World Stress Map database release 2008. doi:10.1594/ GFZ.WSM.Rel2008

Homuth S (2014) Aufschlussanalogstudie zur Charakterisierung oberjurassischer geothermischer Karbonatreservoire im Molassebecken. Dissertation, TU Darmstadt

Jaeger JC, Cook NGW, Zimmermann RW (2007) Fundamentals of rock mechanics, 4th edn. Blackwell, Oxford

Jamaludin SNF, Latiff AHA, Gosh DP (2015) Structural balancing vs horizon flattening on seismic data: example from extensional tectonic setting. IOP Conf Ser Earth Environ Sci 23:1-6

Jolie E, Moeck I, Faulds J (2014) Quantitative structural geology as new exploration method for a fault controlled geothermal system - a case study from the Basin and Range Province, Nevada (USA). Geothermics 54:54-67

Kuhlemann J, Kempf O (2002) Post-Eocene evolution of the North Alpine Foreland basin and its response to Alpine tectonics. Sedim Geol 152:45-78

Lamarche G (1992) Seismic reflection survey in the geothermal field of the Rotorua caldera, New Zealand. Geothermics 21:109-119

Leu W, Mégel T, Schärli U (2006) Geothermische Eigenschaften der Schweizer Molasse Tiefenbereich 0-500 m)—Datenbank für Wärmeleitfähigkeit, spezifische Wärmekapazität, Gesteinsdichte und Porosität. Bericht Schweizer Bundesamt für Energie

Lüschen E, Dussel M, Thomas R, Schulz R (2011) 3D seismic survey for geothermal exploration at Unterhaching, Munich, Germany. First Break 29:45-54

Lüschen E, Wolfgramm M, Fritzer T, Dussel M, Thomas R, Schulz R (2014) 3D seismic survey explores geothermal targets for reservoir characterization at Unterhaching, Munich, Germany. Geothermics 50:167-179

Majer EL (2003) 3-D seismic methods for geothermal reservoir exploration and assessment-summary. Technical Report by the Ernest Orlando Lawrence Berkeley National Laboratory, Berkeley, 33 p. https://www.osti.gov/scitech/biblio/840868. Accessed 24 Mar 2017

Matsushima J, Okubo Y, Rokugawa S, Yokota T, Tanaka K, Tsuchiya T, Narita N (2003) Seismic reflector imaging by prestack time migration in the Kakkonda geothermal field, Japan. Geothermics 32:79-99

Megies T, Wassermann J (2014) Microseismicity observed at a non-pressure-stimulated geothermal power plant. Geothermics 52:36-49

Moeck I, Schandelmeier H, Holl HG (2009a) The stress regime in a Rotliegend reservoir of the Northeast German Basin. Int J Earth Sci (Geol Rundsch) 98:1643-1653. doi:10.1007/ s00531-008-0316-1

Moeck I, Kwiatek G, Zimmermann G (2009b) Slip tendency analysis, fault reactivation potential and induced seismicity in a deep geothermal reservoir. J Struct Geol 31:1174-1182

Moeck I, Uhlig S, Loske B, Jentsch A, Ferreiro Maehlmann R, Hild $S$ (2015a) Fossil multiphase normal faults: prime targets for geothermal drilling in the Bavarian Molasse Basin? In: Proceedings, world geothermal congress, Melbourne, April 20-24, 2015, Australia, 2015. https://www.geothermal-energy.org/pdf/IGAstandard/ WGC/2015/11044.pdf. Accessed 24 Mar 2017

Moeck I, Bloch T, Graf R, Heuberger S, Kuhn P, Naef H, Sonderegger M, Uhlig S, Wolfgramm M (2015b) The St. Gallen Project: development of fault controlled geothermal systems in urban areas. In: Proceedings, world geothermal congress, Melbourne, April 20-24, 2015, Australia, 2015. https://www.geothermalenergy.org/pdf/IGAstandard/WGC/2015/06020.pdf. Accessed 24 Mar 2017

Morris A, Ferrill DA (2009) The importance of the effective intermediate principal stress $\left(\sigma^{\prime} 2\right)$ to fault slip patterns. J Struct Geol 31(9):950-959

Morris A, Ferrill DA, Henderson DB (1996) Slip-tendency analysis and fault reactivation. Geology 24(3):275-278

Nelson EJ, Chipperfield ST, Hillis RR, Gilbert J, McGowen J, Mildren SD (2007) The relationship between closure pressures from fluid injection tests and the minimum principal stress in strong rock. Int J Rock Mech Min Sci 44:787-801

Peška P, Zoback MD (1995) Compressive and tensile failure of inclined well bores and determination of in situ stress and rock strength. J Geophy Res 100(B7):12791-12811

Reinecker J, Tingay M, Müller B, Heidbach O (2010) Present-day stress orientation in the Molasse Basin. Tectonophysics 482:129-138 
Reiter K, Heidbach O, Schmitt D, Haug K, Ziegler M, Moeck I (2014) A revised crustal stress orientation database for Canada. Tectonophysics 636:111-124. doi:10.1016/j.tecto.2014.08.006

Schulz R, Thomas R (HRSG.) (2012) Geothermische Charakterisierung von karstig-klüftigen Aquiferen im Großraum München-Endbericht. LIAG-Bericht. Archiv-Nr. 130 392. Hannover

Schuster R, Stüwe K (2010) Die Geologie der Alpen im Zeitraffer. Mitteilungen des naturwissenschaftlichen Vereines für Steiermark 140:5-21

Scuderi MM, Niemeijer AR, Collettini C, Marone C (2013) Frictional properties and slip stability of active faults within carbonate-evaporite sequences: the role of dolomite and anhydrite. Earth Planet Sci Lett. doi:10.1016/j.epsl.2013.03.024

Thomas R, Unger HJ (2007) Unterhaching geothermal well doublet: structural and hydrodynamic reservoir characteristic; Bavaria (Germany). In: Proceedings European Geothermal Congress 2007

Tvedt ABM, Rotevatn A, Jackson CAL, Fossen H (2013) Growth of normal faults in multilayer sequences: a 3D seismic case study from the Egersund Basin, Norwegian North Sea. J Struct Geol 55:1-20

Vasela P, Lammerer B, Wetzek A, Söllner F, Gerdes A (2008) PostVariscan to Early Alpine sedimentary basins in the Tauern Window 8eastern Alps). Geol Soc Lond Spec Publ 298:83-100. doi: $10.1144 /$ SP298.5

Welbon A (1988) The influence of intrabasinal faults on the development of a linked thrust system. Geol Rundsch 77:11-24

Wolfgramm M (2007) Geologischer Abschlussbericht der Bohrung Gt Unterhaching 2/06. Unpublished internal report. Geothermie Neubrandenburg GmbH

Zoback M, Barton CA, Brudy M, Castillo DA, Finkbeiner T, Grollimund BR, Moss DB, Peska P, Ward CD, Wiprut DJ (2003) Determination of stress orientation and magnitude in deep wells. Int $\mathrm{J}$ Rock Mech Min 40:1049-1076 